L. Al-Khalili • M. Forsgren $\cdot$ K. Kannisto •

J. R. Zierath · F. Lönnqvist - A. Krook

\title{
Enhanced insulin-stimulated glycogen synthesis in response to insulin, metformin or rosiglitazone is associated with increased mRNA expression of GLUT4 and peroxisomal proliferator activator receptor gamma co-activator 1
}

Received: 30 September 2004 / Accepted: 20 December 2004 / Published online: 30 April 2005

(C) Springer-Verlag 2005

\begin{abstract}
Aims/hypothesis: The aim of this study was to determine the effect of several antidiabetic agents on insulin-stimulated glycogen synthesis, as well as on mRNA expression. Methods: Cultured primary human skeletal myotubes obtained from six healthy subjects were treated for 4 or 8 days without or with glucose $(25 \mathrm{mmol} / \mathrm{l})$, insulin (400 pmol/l), rosiglitazone $(10 \mu \mathrm{mol} / \mathrm{l})$, metformin $(20 \mu \mathrm{mol} / \mathrm{l})$ or the AMP-activated kinase activator 5-aminoimidazole4-carboxamide ribonucleoside (AICAR) $(200 \mu \mathrm{mol} / \mathrm{l})$. After this, insulin-stimulated glycogen synthesis was determined. mRNA levels of the glucose transporters GLUT1 and GL UT4, the peroxisomal proliferator activator receptor gamma (PPAR gamma) co-activator 1 (PGC1) and the myocytespecific enhancer factors (MEF2), MEF2A, MEF2C and MEF2D were determined using real-time PCR analysis after 8 days exposure to the various antidiabetic agents. Results: Insulin-stimulated glycogen synthesis was significantly increased in cultured human myotubes treated with insulin, rosiglitazone or metformin for 8 days, compared with non-treated cells. Furthermore, an 8-day exposure of myotubes to $25 \mathrm{mmol} / \mathrm{l}$ glucose impaired insulin-stimulated glycogen synthesis. In contrast, treatment with AICAR was without effect on insulin-mediated glycogen
\end{abstract}

L. Al-Khalili · J. R. Zierath · F. Lönnqvist · A. Krook Department of Surgical Science, Karolinska Institute, Stockholm, Sweden

L. Al-Khalili · J. R. Zierath · A. Krook $(\square)$ Integrative Physiology, Department of Physiology and Pharmacology, Karolinska Institute,

17177 Stockholm, Sweden

e-mail: Anna.Krook@fyfa.ki.se

Tel.: +46-8-52487824

Fax: $+46-8-335436$

M. Forsgren · F. Lönnqvist

Department of Biology, Biovitrum,

Stockholm, Sweden

K. Kannisto

Gustav V Research Institute, Karolinska Hospital,

Stockholm, Sweden synthesis. Exposure to insulin, rosiglitazone or metformin increased mRNA expression of PGC1 and GLUT4, while AICAR or $25 \mathrm{mmol} / \mathrm{l}$ glucose treatment increased GLUT1 mRNA expression. Metformin also increased mRNA expression of the MEF2 isoforms. Conclusions/ interpretation: Enhanced insulin-stimulated glycogen synthesis in human skeletal muscle cell culture coincides with increased GLUT4 and PGC1 mRNA expression following treatment with various antidiabetic agents. These data show that chronic treatment of human myotubes with insulin, metformin or rosiglitazone has a direct positive effect on insulin action and mRNA expression.

Keywords AICAR - GLUT1 - GLUT4 · Glycogen synthesis - Human skeletal muscle - Insulin - MEF2 . Metformin $\cdot$ PGC1 1 Rosiglitazone

Abbreviations AICAR: 5-aminoimidazole-4carboxamide ribonucleoside - AMPK: AMP-activated kinase - MEF2: myocyte-specific enhancer factor 2 . PGC1: peroxisomal proliferator activator receptor gamma co-activator 1 - PPAR: peroxisomal proliferator activator receptor

\section{Introduction}

Elevated plasma glucose levels due to insulin resistance in peripheral tissues or impaired insulin secretion over longer time spans are commonly associated with metabolic aberrations such as insulin resistance, dyslipidaemia, hypertension, obesity and type 2 diabetes mellitus [1-5]. Enhancing insulin action on glucose uptake and metabolism in skeletal muscle, a major insulin target tissue regulating whole-body metabolism, constitutes one possible strategy for normalising glycaemia and glucose homeostasis in insulin-resistant humans. Defects in whole-body glucose uptake are closely linked to impaired insulinstimulated glucose transport activity [6]. GLUT4, the major glucose transporter expressed in skeletal muscle $[7,8]$, 
plays a distinct role in mediating glucose transport under insulin-stimulated conditions [9]. Thus, experimental as well as pharmacological treatment regimes that increase glucose transporter expression have a positive impact on whole-body glucose homeostasis [10-12].

Genes dependent on myocyte-specific enhancer factor 2 (MEF2) encode a wide array of proteins, including musclespecific enzymes, structural proteins and other transcription factors. Through high-affinity binding to the GLUT4 gene promoter [13], MEF2 regulates GLUT4 expression in skeletal muscle and adipose tissue [14]. The GLUT4 MEF2 site $(-473 /-464)$ is required for tissue-specific and hormonal/ metabolic regulation of glucose transporters [15], providing a link between this transcription factor and GLUT4 regulation. MEF2A, MEF2C and MEF2D isoforms, but not the MEF2B isoform, are expressed in skeletal muscle and heart [16, 17], and functional differences among the MEF2 isoforms exist [18]. In skeletal muscle and heart of diabetic mice, MEF2 DNA-binding activity is substantially reduced and correlated with a decrease in GLUT4 transcription rate. MEF2 DNA binding activity is completely normalised after insulin treatment. Peroxisomal proliferator activator receptor (PPAR) gamma co-activator (PGC) 1 is a coactivator of MEF2 [19]. PGC1 has recently been highlighted as an important regulator of gluconeogenesis, fatty-acid oxidation and adaptive thermogenesis [20]. Moreover, PGC1 expression is reduced in skeletal muscle of prediabetic and diabetic subjects [21]. We hypothesised that MEF2 isoforms and PGC1 play a critical role in skeletal muscle metabolism and that activation of these targets may enhance the metabolic profile of skeletal muscle.

Several pharmacological agents have been tested for their relative effects on insulin action and the potential for prevention of the metabolic syndrome [22-25]. Thiazolidinediones (i.e. PPAR gamma agonists such as rosiglitazone) act primarily on peripheral insulin sensitivity and also have positive effects on fasting levels of NEFA and inflammatory markers [26-28]. Conversely, metformin acts mainly on the liver, at least partly through activation of AMP-activated kinase (AMPK) [29]. AICAR (5-aminoimidazole-4-carboxamide ribonucleoside) is an adenosine analogue, which also acts through AMPK [30], but in a more selective manner than metformin. AICAR treatment decreases blood glucose and insulin concentrations in animals, but the safety profile of this compound remains unclear [31]. The effect of these treatments on gene regulatory responses in human skeletal muscle is largely unknown. We determined the effect of long-term treatment of these diverse antidiabetic drugs on glucose transporters and transcription factors involved in insulin sensitivity and gene regulatory responses in primary human skeletal muscle cultures.

\section{Subjects, materials and methods}

Subject characteristics Muscle biopsies were obtained with the informed consent of the donors during scheduled abdominal surgery. The subjects (three men, three women) had no known metabolic disorder. Their mean age was $43 \pm$
6.7 years, BMI was $26 \pm 2.4$ and fasting blood glucose was $5.3 \pm 0.3 \mathrm{mmol} / \mathrm{l}$. The ethical committee at the Karolinska Institute approved the study protocols.

Materials DMEM, Ham's F-10 medium, fetal bovine serum, penicillin, streptomycin and Fungizone were obtained from Gibco BRL (Invitrogen, Stockholm, Sweden). Rosiglitazone was a generous gift from Glaxo SmithKline (Middlesex, UK). Myotubes were treated with rosiglitazone, metformin (1,1-dimethylbiguanide; Sigma, St Louis, MO, USA), AICAR (Sigma) or insulin (Actrapid; Novo Nordisk, Gentofte, Denmark) as described below. The polyclonal GLUT4 antiserum was generated by $\mathrm{H}$. Haspel and kindly provided by A. Lange (University of Minnesota, Minneapolis, MN, USA).

Cell culture and differentiation Muscle biopsies (rectus abdominus, $\sim 1-3 \mathrm{~g}$ ) were collected in cold PBS supplemented with $1 \%$ PeSt (100 units $/ \mathrm{ml}$ penicillin $/ 100 \mu \mathrm{g} / \mathrm{ml}$ streptomycin). Satellite cells were isolated and cultured as described [32]. Myoblasts were grown in growth medium $(5.5 \mathrm{mmol} / \mathrm{l}$ glucose Ham's F-10 medium $/ 20 \%$ fetal calf serum), which was replaced, when differentiation was initiated, with differentiation medium $(5.5 \mathrm{mmol} / 1$ glucose DMEM $/ 4 \%$ fetal calf serum for 2 days, thereafter $2 \%$ fetal calf serum). Differentiation of myoblasts to myotubes was started with 8-day treatment without or with rosiglitazone $(10 \mu \mathrm{mol} / \mathrm{l})$, insulin $(400 \mathrm{pmol} / \mathrm{l})$, metformin $(20 \mu \mathrm{mol} / \mathrm{l})$, AICAR $(200 \mu \mathrm{mol} / \mathrm{l})$ and glucose $(25 \mathrm{mmol} / \mathrm{l})$. The final concentration of DMSO was adjusted to $0.1 \%$ for each group (without or with reagents). On the day of the assay, the myotubes were washed free of reagents and incubated with serum-free DMEM for $6 \mathrm{~h}$ and used for RNA analysis.

Giemsa/Wright staining To assess the extent of differentiation, myotubes were fixed in methanol $(10 \mathrm{~min}), 1: 10$ Giemsa (15 min) and 1:10 Wright stain (20 min). Cells were washed with double-distilled water and mono- or multinucleated cells were observed under a phase-contrast inverted light microscope.

Glycogen synthesis The glycogen synthesis assay procedure was performed as described [33]. Myotubes in 6-well dishes were treated as described above and were serumstarved for $6 \mathrm{~h}$ prior to assay. Thereafter, myotubes were stimulated without or with insulin $(6$ or $60 \mathrm{nmol} / \mathrm{l})$ for 30 min at $37^{\circ} \mathrm{C}$ and incubated with $5 \mathrm{mmol} / 1$ glucose DMEM, supplemented with $\mathrm{D}-\left[\mathrm{U}-{ }^{14} \mathrm{C}\right]$ glucose $(18 \mathrm{kBq} / \mathrm{ml}$; final specific activity $6.66 \mathrm{kBq} / \mu \mathrm{mol}$ ) for $90 \mathrm{~min}$. Each experiment was performed on duplicate wells.

Real-time PCR analysis of $m R N A$ expression Cells were cultured in $100 \mathrm{mmol} / \mathrm{l}$ dishes as described above. Cultures were washed three times with RNase-free PBS, and harvested directly for RNA extraction (RNAeasy Mini Kit; Qiagen, Crawley, UK). All RNA was DNase-treated before reverse transcription (RQ1 RNase-free DNase; Promega, Southampton, UK). The mRNA concentrations of target genes were determined, and cDNA $(50 \mu \mathrm{l})$ was prepared 
Table 1 Primer and probe sequences used for real time PCR analysis

\begin{tabular}{llll}
\hline & Sense & Probe & Antisense \\
\hline MEF2A & CAGCACCACCTAGGACAAGCA & CTCAGCTCTCTTGTTG & TGGATAAATTGGAACC \\
& & CTGGAGGGCA & CTGAGATAA \\
MEF2C & CCTACATAACATGCCACCATCTG & TCAGTCAGTTGGGAG & AGGGAGAGATTTGAA \\
& & CTTGCACTAGCAC & CTCTGAGATAAA \\
MEF2D & CGCTCTTTGCCGTGACAAC & CCGGGCTGGAGGC & GTTCATGGTCTGCAG \\
& & TGTGC & GATACCTT \\
hGLUT-4 & GCTACCTCTACATCATCCAGAATCTC & CTGCCAGAAAGAGT & CCAGAAACATCGGCCCA \\
hGLUT-1 & CCTGTGGGAGCCTGCAAA & CTGAAGCGCCT & TCTATACACAACAGG \\
hPGC1 & & CACTGCTCAAGAAGAC & GCAGGAGTCT \\
& AGAGACAAATGCACCTCCAAAAA & AAGTCCCACACACAGT & AAAGTTGTGGTTGG \\
\hline
\end{tabular}

Human 18S primer/probe complexes were from assays-on-demand products, Applied Biosystems. The primers and probe concentrations ranged from 300 to $900 \mathrm{nmol} / 1$

from $1 \mu \mathrm{g}$ RNA samples using the TaqMan reverse transcription reagent (Applied Biosystems, Foster City, CA, USA). The cDNA products were diluted fourfold before use. The quantification of PCR products was analysed by real-time PCR (TaqMan) using a standard curve method (User Bulletin 2, ABI PRISM 7900 Sequence Detection System). All samples $(1 \mu$ per well for real-time PCR analysis) were analysed in triplicate. The ABI Prism 7900 HT Sequence Detection System (Applied Biosystems) was used for analysis. The sequences of the primers and probes were either designed using published data (PubMed) or Primer Express software (Perkin Elmer, Wellesley, MA, USA), or acquired by assays-on-demand (Applied Biosystems). The primer and probe sequences are given in Table 1 . To verify the lack of contamination by genomic DNA, each sample was run in parallel under identical conditions, but containing a sample in which the reverse transcription reagent had been omitted from the cDNA synthesis. The control samples indicated that there was no genomic contamination in the total RNA preparation (data not shown). All data were analysed by using the values of the $18 S$ gene levels as a baseline. Two other housekeeping genes $\left(\beta_{2}\right.$ microglobulin and GAPDH) were also assessed, but the $18 S$ gene levels showed least variation between different conditions.

Western blot analysis Cell monolayers were washed once in ice-cold PBS and harvested directly by scraping into icecold lysis buffer $\left(135 \mathrm{mmol} / 1 \mathrm{NaCl}, 1 \mathrm{mmol} / 1 \mathrm{MgCl}_{2}, 2.7\right.$ $\mathrm{mmol} / 1 \mathrm{KCl}, 20 \mathrm{mmol} / \mathrm{l}$ Tris $\mathrm{pH} 8.0,0.5 \mathrm{mmol} / 1 \mathrm{Na}_{3} \mathrm{VO}_{4}$, $10 \mathrm{mmol} / \mathrm{l} \mathrm{NaF}, 1 \%$ Triton X-100, $10 \% \mathrm{v} / \mathrm{v}$ glycerol, 0.2 $\mathrm{mmol} / \mathrm{l}$ phenylmethylsulphonyl, $10 \mu \mathrm{g} / \mathrm{ml}$ leupeptin, $10 \mu \mathrm{g} / \mathrm{ml}$ antipain and $10 \mu \mathrm{g} / \mathrm{ml}$ aprotinin). Homogenates were rotated for $60 \mathrm{~min}$ at $4^{\circ} \mathrm{C}$ and subjected to centrifugation $(20,000 \times g)$ for $10 \mathrm{~min}$ at $4^{\circ} \mathrm{C}$. Following protein determination, western blotting was performed as described [18].
Fig. 1 Effect of acute $(20 \mathrm{~min})$ exposure to antidiabetic agents on glycogen synthesis. Myotubes were treated with rosiglitazone (Rosi) $(10 \mu \mathrm{mol} / \mathrm{l})$, insulin $(60 \mathrm{nmol} / \mathrm{l})$, metformin $(20 \mu \mathrm{mol} / \mathrm{l})$ or AICAR $(200 \mu \mathrm{mol} / \mathrm{l})$. Glycogen synthesis was calculated as picomoles of glucose per milligram per minute. Data are percentages of basal condition \pm SEM $(n=5) . * p<0.05$; ${ }^{\#} p<0.005$

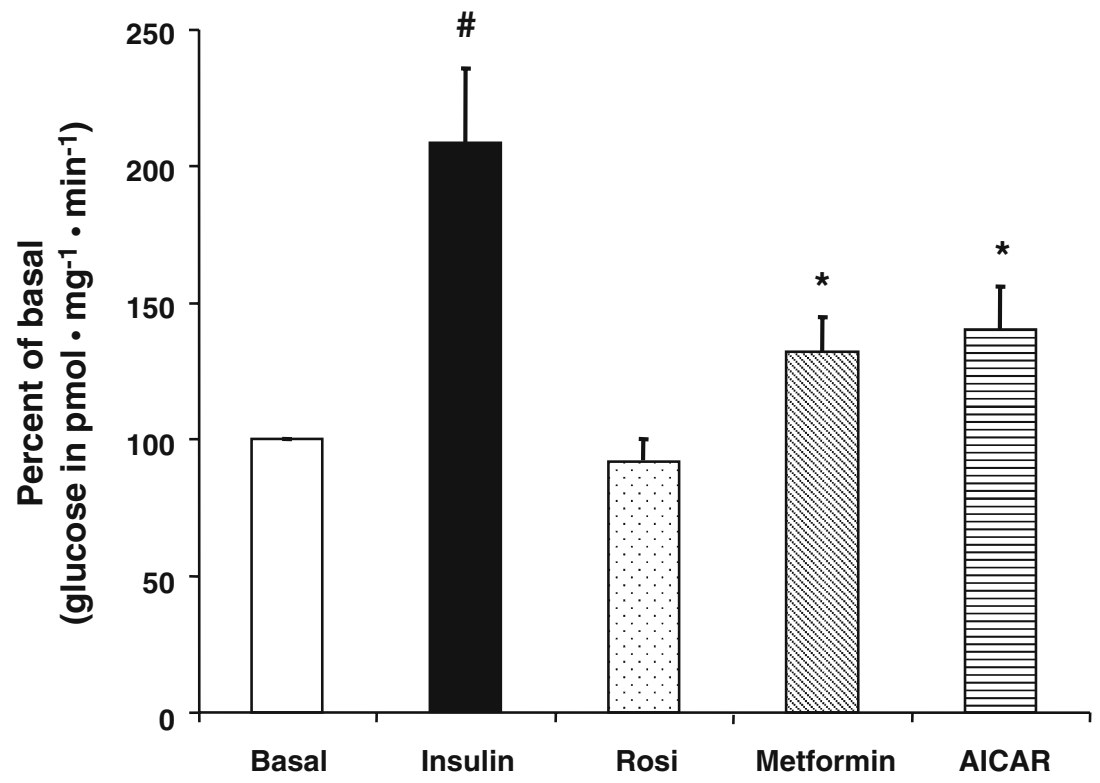




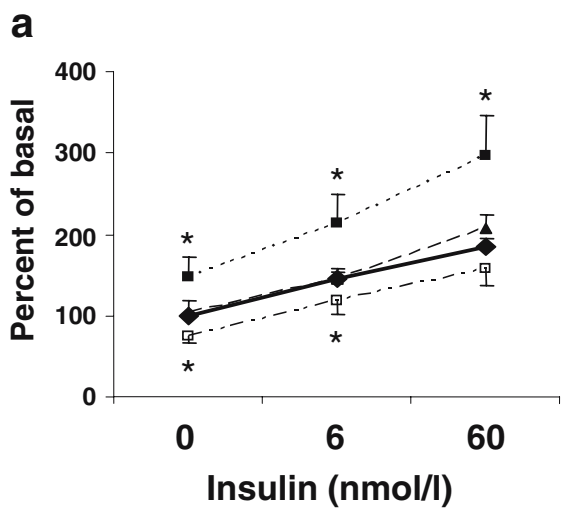

Fig. 2 Effect of chronic exposure (8 days) to antidiabetic agents on basal and insulin-stimulated (6 and $60 \mathrm{nmol} / \mathrm{l})$ glucose incorporation into glycogen. Myotubes were treated for 8 days without or with rosiglitazone $(10 \mu \mathrm{mol} / \mathrm{l})$, insulin $(400 \mathrm{pmol} / \mathrm{l})$, metformin $(20 \mu \mathrm{mol} / \mathrm{l})$, AICAR $(200 \mu \mathrm{mol} / \mathrm{l})$ or glucose $(25 \mathrm{mmol} / \mathrm{l})$. a Comparison of glycogen synthesis between basal (diamonds and solid line), insulin (solid squares and dotted line), AICAR (solid triangles and dashed

Statistical analysis Data are presented as means \pm SEM. Statistical differences were determined by Student's $t$-test or ANOVA using Fisher's least significant difference test for post hoc determination. Significance was accepted at a $p$ value of $p<0.05$.

\section{Results}

Cell morphology Myotubes were stained with Giemsa/ Wright staining in order to follow the morphological changes in myotubes after long-term stimulation with different agents. Cell detachment, multinucleation of myotubes and cell death were unaltered when untreated and treated myotubes were compared (data not shown).

Glycogen synthesis The effect of acute $(20 \mathrm{~min})$ exposure to insulin $(60 \mathrm{nmol} / \mathrm{l})$, rosiglitazone $(10 \mu \mathrm{mol} / \mathrm{l})$, metformin $(20 \mu \mathrm{mol} / \mathrm{l})$ or AICAR $(200 \mu \mathrm{mol} / \mathrm{l})$ on glycogen synthesis was determined in primary human skeletal muscle cultures (Fig. 1). Insulin treatment increased glycogen synthesis twofold $(p<0.05)$. Acute exposure to rosiglitazone did not alter glycogen synthesis. In contrast, metformin and AI CAR treatment each led to a modest increase in glycogen synthesis (1.3- and 1.4-fold, $p<0.05$ for both).

The chronic effect (4- or 8-day exposure) on glycogen synthesis of insulin $(400 \mathrm{pmol} / \mathrm{l})$, glucose $(25 \mathrm{mmol} / \mathrm{l})$, rosiglitazone $(10 \mu \mathrm{mol} / \mathrm{l})$, metformin $(20 \mu \mathrm{mol} / \mathrm{l})$ or $\mathrm{AI}$

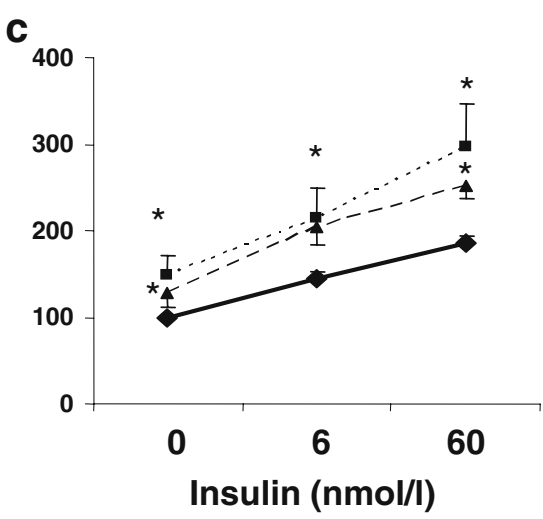

line) and glucose (open squares and dashed/dotted line). b Comparison of glycogen synthesis between basal (as a), insulin (as a) and metformin (solid triangles and dashed line). c Comparison of glycogen synthesis between basal (as a), insulin (as a) and rosiglitazone (solid triangles and dashed line). Data are percentages of basal condition $\pm \operatorname{SE}(n=6) .{ }^{*} p<0.05$ compared with same condition in untreated (basal) cells

CAR (200 $\mu \mathrm{mol} / \mathrm{l})$ was determined (Fig. 2). Myotubes were washed prior to measurement of basal and insulin-stimulated glycogen synthesis. Four days of exposure to 25 $\mathrm{mmol} / \mathrm{l}$ glucose reduced the action of insulin on glycogen synthesis. This effect was even more pronounced after 8 days exposure to $25 \mathrm{mmol} / \mathrm{l}$ glucose. Chronic exposure to insulin, rosiglitazone, metformin or AICAR for 4 days increased basal glycogen synthesis, but was without effect on insulin-mediated glycogen synthesis (data not shown).

Exposure of myotubes for 8 days to $400 \mathrm{pmol} / 1$ insulin was associated with an increase in basal $(148 \%, p<0.05)$ and insulin-stimulated (at 6 and $60 \mathrm{nmol} / \mathrm{l}$ insulin concentration respectively, $p<0.05$ ) glycogen synthesis. Eight days of chronic exposure to glucose reduced basal $(26 \%$ decrease, $p<0.05)$ and insulin-stimulated glycogen synthesis $(20$ and $15 \%$ decrease with 6 and $60 \mathrm{nmol} / 1$ insulin, respectively, $p<0.05$; Fig. 2a) compared with untreated myotube cultures. Metformin (Fig. 2a) and rosiglitazone (Fig. 2b) increased basal (120 and 127\% respectively) and insulin-stimulated glycogen synthesis at high insulin concentrations (125 and $136 \%$ respectively, $p<0.05$ ). AICAR (Fig. 2c) did not increase basal glycogen synthesis but increased insulin-stimulated glycogen synthesis moderately in the presence of $60 \mathrm{nmol} / 1$ insulin $(113 \%, p<0.05)$.

$m R N A$ expression The chronic effect of insulin $(400 \mathrm{pmol} /$ 1), glucose $(25 \mathrm{mmol} / \mathrm{l})$, rosiglitazone $(10 \mu \mathrm{mol} / \mathrm{l})$, metfor$\min (20 \mu \mathrm{mol} / \mathrm{l})$ or AICAR $(200 \mu \mathrm{mol} / \mathrm{l})$ on mRNA expres-
Table 2 mRNA expression profile in primary human skeletal muscle myotubes after 8 days exposure to insulin, rosiglitazone, metformin, AICAR or hyperglycaemia

${ }^{\mathrm{a}} p<0.05$ vs untreated myotubes (basal)

\begin{tabular}{lllllcl}
\hline Treatment & PGC1 & GLUT4 & GLUT1 & MEF2a & MEF2c & MEF2d \\
\hline Basal & $100 \pm 0$ & $100 \pm 0$ & $100 \pm 0$ & $100 \pm 0$ & $100 \pm 0$ & $100 \pm 0$ \\
Insulin & $163 \pm 22^{\mathrm{a}}$ & $222 \pm 38^{\mathrm{a}}$ & $110 \pm 11$ & $110 \pm 9$ & $115 \pm 7^{\mathrm{a}}$ & $105 \pm 6$ \\
AICAR & $114 \pm 15$ & $139 \pm 24$ & $175 \pm 17^{\mathrm{a}}$ & $111 \pm 7$ & $81 \pm 7^{\mathrm{a}}$ & $105 \pm 11$ \\
Metformin & $195 \pm 35^{\mathrm{a}}$ & $179 \pm 22^{\mathrm{a}}$ & $121 \pm 21$ & $142 \pm 11^{\mathrm{a}}$ & $165 \pm 24^{\mathrm{a}}$ & $149 \pm 17^{\mathrm{a}}$ \\
Rosiglitazone & $169 \pm 24^{\mathrm{a}}$ & $177 \pm 24^{\mathrm{a}}$ & $130 \pm 21$ & $109 \pm 4$ & $99 \pm 8$ & $110 \pm 9$ \\
Glucose & $160 \pm 35$ & $119 \pm 19$ & $129 \pm 11^{\mathrm{a}}$ & $101 \pm 9$ & $99 \pm 13$ & $112 \pm 11$ \\
\hline
\end{tabular}


Fig. 3 a Protein expression of GLUT4 in lysates from myotubes treated for 8 days without or with rosiglitazone $(10 \mu \mathrm{mol} / \mathrm{l})$, insulin (400 pmol/1), metformin $(20 \mu \mathrm{mol} / \mathrm{l})$, AICAR $(200 \mu \mathrm{mol} / \mathrm{l})$ or glucose $(25 \mathrm{mmol} / \mathrm{l})$. Graph shows summarised data from four separate subjects; inset shows a representative autoradiogram. b Correlation between changes in insulin-stimulated glycogen synthesis and GLUT4 mRNA expression. Changes in insulin-stimulated glycogen synthesis were calculated as the difference between untreated and treated cells exposed to $60 \mathrm{nmol} / 1$ insulin, expressed as picomoles of glucose per milligram per minute. Changes in mRNA expression were related to the difference in mRNA expression compared with untreated cultures, which were set at $100 \%$

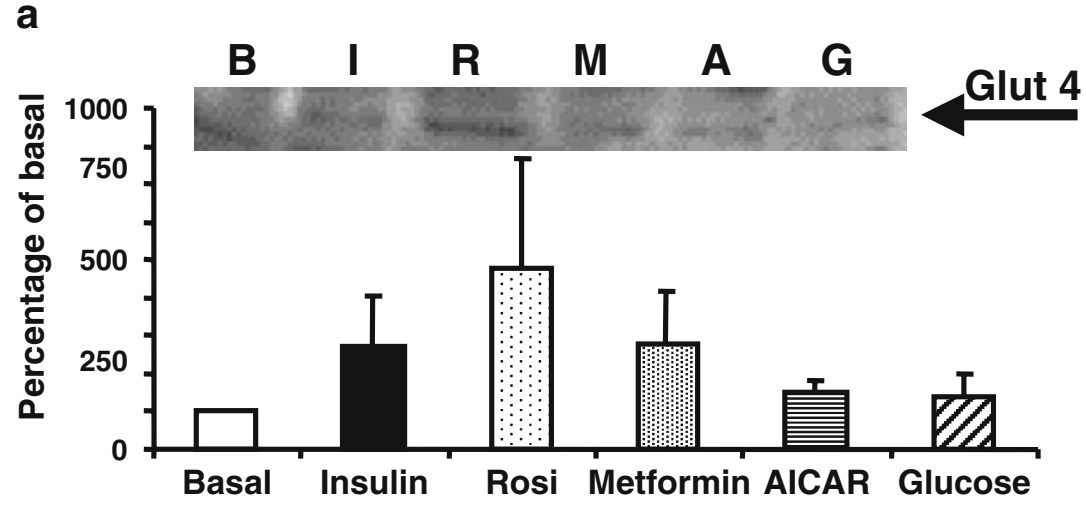

b

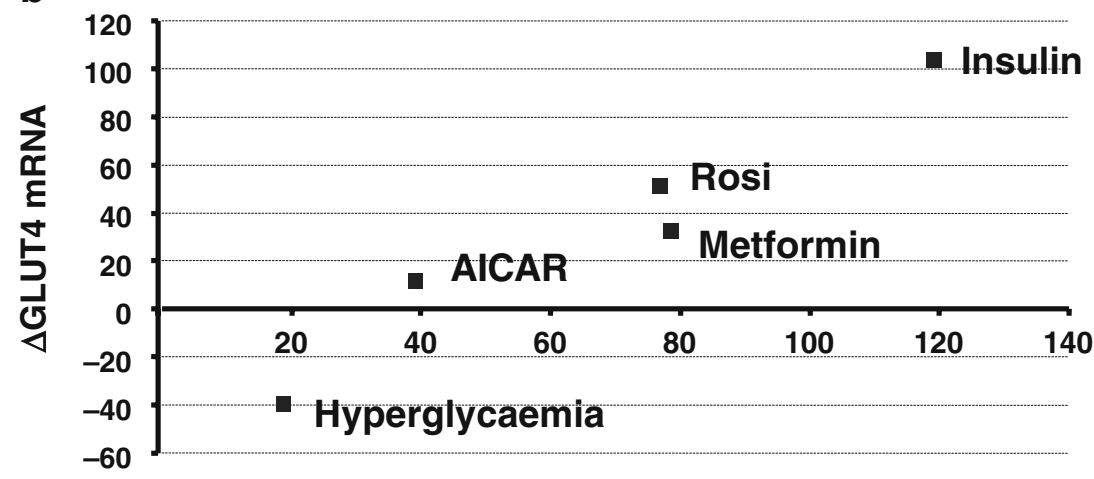

\section{$\Delta$ Insulin-stimulated glycogen synthesis}

sion of glucose transporters and transcription factors was determined (Table 2). Exposure to insulin, rosiglitazone or metformin increased PGC1 mRNA expression. Similarly, exposure to insulin, rosiglitazone or metformin increased GLUT4 mRNA and protein expression (Table 2 and Fig. 3a). Furthermore, the increase in insulin-stimulated glycogen synthesis was positively correlated with the increase in GLUT4 mRNA (Fig. 3b).

AICAR treatment increased GLUT1 mRNA and decreased MEF2C mRNA expression. Metformin increased mRNA expression of all MEF2 isoforms. Insulin led to a selective increase in MEF2C mRNA expression, with no effect noted on the other MEF2 isoforms. Exposure to high glucose concentrations $(25 \mathrm{mmol} / \mathrm{l})$ increased GLUT1 mR NA expression, but was without effects on the other genes.

\section{Discussion}

Therapeutic agents that effectively and selectively target skeletal muscle insulin sensitivity are lacking. Currently available antidiabetic drugs mainly target beta cell function (sulphonylureas), hepatic glucose output (metformin) or adipose tissue (thiazolidinediones). However, several of the existing antidiabetic drugs appear to have at least some additional (direct or indirect) effects on skeletal muscle. In this study we provide evidence that treatment of human skeletal muscle cells with antidiabetic agents increases in- sulin-stimulated glycogen synthesis. Moreover, the improvement in insulin action after exposure to these treatments is correlated with increased mRNA expression of GLUT4.

Defects in skeletal muscle glycogen synthesis have been shown to play a central role in insulin resistance [34]. Targeted antisense-mediated reduction of glycogen synthase protein in cultured muscle leads to reduced insulin action [35]. In this context, glycogen synthase activity, hexokinase activity and glucose transport are all considered important rate-controlling factors contributing to glucose homeostasis [36]. Exposure of human myotubes to a high concentration of glucose for 8 days impaired insulin action on glycogen synthesis. Our results are consistent with previous work showing that 4 days of hyperglycaemia reduces basal [37] and insulin-stimulated glycogen synthesis $[37,38]$.

Whether high glucose treatment slows or decreases the differentiation of myocytes to myotubes is unknown. However, the morphological profile of the myotubes was unchanged following any of the treatments investigated here. The increased glycogen synthesis and mRNA expression of PGC1, GLUT4 and MEF2C after long-term treatment with insulin may suggest enhanced myogenesis, although this is unlikely since the morphological pattern was unaltered. Marked changes in morphology and skeletal muscle cell differentiation have been reported following 5 days of exposure to high concentrations of troglitazone, another thiazolidinedione [39]. However, after rosiglitazone exposure, the morphology of the primary human skeletal muscle cells 
was unaltered. The difference between rosiglitazone and troglitazone in their effects on muscle morphology may be due to differences in the concentration of glitazone studied or a compound-specific effect. Interestingly, short-term exposure (1 day) of primary human muscle cells to troglitazone enhanced insulin action, similar to the results reported here for rosiglitazone [39].

Most in vitro studies conducted to dissect the effects of rosiglitazone and metformin on metabolic and gene-regulatory responses have been performed using adipocytes or hepatocytes. Direct effects of troglitazone have previously been reported on cell lipid metabolism [40], gene expression [41] and glucose uptake [39, 42] in human skeletal muscle. Here we report that 8 days of rosiglitazone treatment increases glycogen synthesis in the absence or presence of insulin, and these changes are accompanied by increased expression of GLUT4 and PGC1 mRNA. In our hands, GLUT4 and GLUT1 mRNA and protein expression are positively correlated in differentiating human skeletal muscle cells (data available upon request). In contrast to these findings, in L6 myotubes rosiglitazone has been suggested to increase GLUT4 translocation, but not protein or mRNA content [43]. However, this particular conclusion was based on a much shorter rosiglitazone exposure ( $24 \mathrm{~h})$, which may be insufficient to mediate generegulatory responses. Furthermore, in soleus muscle from insulin-resistant $\mathrm{PD} / \mathrm{Cub}$ rats, 14 days of rosiglitazone treatment increased insulin-stimulated glycogen synthesis [44]. Thus, in human muscle cells, part of the insulin-sensitising effect of rosiglitazone can be attributed to changes in mRNA and protein expression of glucose transporters.

AICAR activates AMPK and stimulates glucose uptake in skeletal muscle [45]. In the present study, acute AICAR treatment increased glycogen synthesis, while chronic (8 days) AICAR treatment was without effect on insulin action, as assessed by glycogen synthesis, or expression of GLUT4 or PGC1 mRNAs. The acute responses are consistent with findings in rat skeletal muscle $[31,46]$ and perfused hindlimb [47], where AICAR treatment increased GLUT4 expression and translocation respectively. Furthermore, chronic AICAR treatment of Clone 9 cells increased glucose uptake [48]. Based on the observation that GLUT1 content was unchanged in the plasma membranes of AICAR-treated Clone 9 cells, the effects on glucose uptake were proposed to activate pre-existing plasma membrane GLUT1 transporters. Nevertheless, our present data reveal that chronic AICAR treatment in human myotubes selectively increases GLUT1, but not GLUT4, expression. Moreover, in human myotubes exposed to AICAR for 8 days, mRNA expression of MEF2C was reduced. Whether AICAR has a negative effect on the regulation of myogenesis in this cell system remains to be demonstrated, but no such effects have previously been suggested. However, MEF2C is involved in the regulation of differentiation-specific genes [16] and suppression of this gene may repress gene-regulatory responses.

Metformin treatment of cells increases GLUT4 recruitment and increases glycogen synthesis [49]. Here we demonstrate that chronic metformin exposure increases the expression of GLUT4, PGC1 and all MEF2 isoforms (A, C and D) and increases the rate of basal and insulin-stimulated glycogen synthesis. Metformin has been suggested to increase AMPK activity [29]. Interestingly, in human myotubes, metformin treatment was more potent than AICAR in increasing GLUT4 expression and in enhancing insulin sensitivity, suggesting that metformin activates additional AMPK-independent pathways.

In summary, exposure of human myotubes to metformin and rosiglitazone, two currently available antidiabetic agents, was associated with direct enhancement of the action of insulin in cultured skeletal muscle. The increase in insulin action correlated with increased mRNA expression of GLUT4. Increased expression of PGC1, GLUT4 and MEF2 mRNA after antidiabetic treatment provides a molecular mechanism for increased carbohydrate metabolism, cellular survival and gene-regulatory responses that confer improved skeletal muscle metabolic function in insulinresistant and diabetic subjects.

Acknowledgements This study was supported by grants from the Swedish Research Council, the Thurings Foundation, the Swedish Medical Association, Tore Nilsons Stiftelse, the Novo-Nordisk Foundation, Harald and Greta Jeanssons Stiftelse, the Swedish Diabetes Association, the Markus and Amalia Wallenberg Foundation, the Swedish Fund for Research without Animal Experiments and the Swedish Central Board for Research Animal Welfare.

\section{References}

1. McGarry JD (1998) Glucose-fatty acid interactions in health and disease. Am J Clin Nutr 67:500S-504S

2. Boden G (1997) Role of fatty acids in the pathogenesis of insulin resistance and NIDDM. Diabetes 46:3-10

3. Ciaraldi TP, Abrams L, Nikoulina S, Mudaliar S, Henry RR (1995) Glucose transport in cultured human skeletal muscle cells. Regulation by insulin and glucose in nondiabetic and non-insulin-dependent diabetes mellitus subjects. J Clin Invest 96:2820-2827

4. Kelley DE, Goodpaster BH (2001) Effects of exercise on glucose homeostasis in type 2 diabetes mellitus. Med Sci Sports Exerc 33:S495-S501

5. Lewis GF, Carpentier A, Adeli K, Giacca A (2002) Disordered fat storage and mobilization in the pathogenesis of insulin resistance and type 2 diabetes. Endocr Rev 23:201-229

6. Zierath JR, Krook A, Wallberg-Henriksson H (2000) Insulin action and insulin resistance in human skeletal muscle. Diabetologia 43:821-835

7. Charron MJ, Brosius FC III, Alper SL, Lodish HF (1989) A glucose transport protein expressed predominately in insulinresponsive tissues. Proc Natl Acad Sci U S A 86:2535-2539

8. James DE, Strube MM, Mueckler MM (1989) Molecular cloning and characterization of an insulin-regulatable glucose transporter. Nature 338:83-87

9. Tsao T-S, Stenbit A, Li J et al (1997) Muscle-specific transgenic complementation of GLUT4-deficient mice: preferential effects of glucose but not lipid metabolism. J Clin Invest 100: 671-677

10. Shepherd PR, Gnudi L, Tozzo E et al (1993) Adipose cell hyperplasia and enhanced glucose disposal in transgenic mice overexpressing GLUT4 selectively in adipose tissue. J Biol Chem 268:22243-22246

11. Torrance CJ, Devente JE, Jones JP, Dohm GL (1997) Effects of thyroid hormone on GLUT4 glucose transporter gene expression and NIDDM in rats. Endocrinology 138:1204-1214 
12. Gibbs EM, Stock JL, McCoid SC et al (1995) Glycemic improvement in diabetic $d b / d b$ mice by overexpression of the human insulin-regulatable glucose transporter (GLUT4). J Clin Invest 95:1512-1518

13. Mora S, Pessin JE (2000) The MEF2A isoform is required for striated muscle-specific expression of the insulin-responsive GLUT4 glucose transporter. J Biol Chem 275:16323-16328

14. Thai MV, Guruswamy S, Cao KT, Pessin JE, Olson AL (1998) Myocyte enhancer factor 2 (MEF2)-binding site is required for GLUT4 gene expression in transgenic mice: regulation of MEF2 DNA binding activity in insulin-deficient diabetes. J Biol Chem 273:14285-14292

15. Tsunoda N, Cooke DW, Ikemoto S et al (1997) Regulated expression of 5'-deleted mouse GLUT4 minigenes in transgenic mice: effects of exercise training and high-fat diet. Biochem Biophys Res Commun 239:503-509

16. McKinsey TA, Zhang CL, Olson EN (2002) MEF2: a calciumdependent regulator of cell division, differentiation and death. Trends Biochem Sci 27:40-47

17. Mora S, Yang C, Ryder JW, Boeglin D, Pessin JE (2001) The MEF2A and MEF2D isoforms are differentially regulated in muscle and adipose tissue during states of insulin deficiency. Endocrinology 142:1999-2004

18. Al-Khalili L, Chibalin AV, Yu M et al (2004) MEF2 activation in differentiated primary human skeletal muscle cultures requires coordinated involvement of parallel pathways. Am J Physiol Cell Physiol 286:C1410-C1416

19. Handschin C, Rhee J, Lin J, Tarr PT, Spiegelman BM (2003) An autoregulatory loop controls peroxisome proliferator-activated receptor $\gamma$ coactivator $1 \alpha$ expression in muscle. Proc Natl Acad Sci U S A 100:7111-7116

20. Puigserver P, Wu Z, Park WC et al (1998) A cold-inducible coactivator of nuclear receptors linked to adaptive thermogenesis. Cell 92:829-839

21. Patti ME, Butte AJ, Crunkhorn S et al (2003) Coordinated reduction of genes of oxidative metabolism in humans with insulin resistance and diabetes: potential role of PGC1 and NRF1. Proc Natl Acad Sci U S A 100:8466-8471

22. Sood V, Colleran K, Burge MR (2000) Thiazolidinediones: a comparative review of approved uses. Diabetes Technol Ther 2:429-440

23. Reasner CA (1999) Promising new approaches. Diabetes Obes Metab 1:S41-S48

24. Mauvais-Jarvis F, Andreelli F, Hanaire-Broutin H, Charbonnel B, Girard J (2001) Therapeutic perspectives for type 2 diabetes mellitus: molecular and clinical insights. Diabetes Metab 27: 415-423

25. Nambi V, Hoogwerf RJ, Sprecher DL (2002) A truly deadly quartet: obesity, hypertension, hypertriglyceridemia, and hyperinsulinemia. Cleve Clin J Med 69:985-989

26. Ciaraldi TP, Kolterman OG, Scarlett JA, Kao M, Olefsky JM (1982) Role of glucose transport in the postreceptor defect of non-insulin-dependent diabetes mellitus. Diabetes 31:10161022

27. Garg R, Tripathy D, Dandona P (2003) Insulin resistance as a proinflammatory state: mechanisms, mediators, and therapeutic interventions. Curr Drug Targets 4:487-492

28. Mayerson AB, Hundal RS, Dufour S et al (2002) The effects of rosiglitazone on insulin sensitivity, lipolysis, and hepatic and skeletal muscle triglyceride content in patients with type 2 diabetes. Diabetes 51:797-802

29. Ruderman NB, Cacicedo JM, Itani S et al (2003) Malonyl-CoA and AMP-activated protein kinase (AMPK): possible links between insulin resistance in muscle and early endothelial cell damage in diabetes. Biochem Soc Trans 31:202-206

30. Musi N, Hirshman MF, Nygren J et al (2002) Metformin increases AMP-activated protein kinase activity in skeletal muscle of subjects with type 2 diabetes. Diabetes 51:20742081

31. Song XM, Fiedler M, Galuska D et al (2002) 5-Aminoimidazole-4-carboxamide ribonucleoside treatment improves glucose homeostasis in insulin-resistant diabetic $(o b / o b)$ mice. Diabetologia 45:56-65
32. A1-Khalili L, Krämer D, Wretenberg P, Krook A (2004) Enhanced insulin-mediated ERK1/2 MAPK and Akt/PKB phosphorylation in cultured human myocytes post differentiation. Acta Physiol Scand 180:395-403

33. Al-Khalili L, Chibalin AV, Kannisto K et al (2003) Insulin action in cultured human skeletal muscle cells during differentiation: assessment of cell surface GLUT4 and GLUT1 content. Cell Mol Life Sci 60:991-998

34. Cline GW, Petersen KF, Krssak M et al (1999) Impaired glucose transport as a cause of decreased insulin-stimulated muscle glycogen synthesis in type 2 diabetes. N Engl J Med 341:240-246

35. Park KS, Ciaraldi TP, Carter L et al (2000) Induction of insulin resistance in human skeletal muscle cells by downregulation of glycogen synthase protein expression. Metabolism 49:962-968

36. Gaster M, Petersen I, Hojlund K, Poulsen P, Beck-Nielsen H (2002) The diabetic phenotype is conserved in myotubes established from diabetic subjects: evidence for primary defects in glucose transport and glycogen synthase activity. Diabetes 51:921-927

37. Gaster M, Schroder HD, Handberg A, Beck-Nielsen H (2001) The basal kinetic parameters of glycogen synthase in human myotube cultures are not affected by chronic high insulin exposure. Biochim Biophys Acta 1537:211-221

38. Henry RR, Ciaraldi TP, Mudaliar S, Abrams L, Nikoulina SE (1996) Acquired defects of glycogen synthase activity in cultured human skeletal muscle cells: influence of high glucose and insulin levels. Diabetes 45:400-407

39. Kausch C, Krutzfeldt J, Witke A et al (2001) Effects of troglitazone on cellular differentiation, insulin signaling, and glucose metabolism in cultured human skeletal muscle cells. Biochem Biophys Res Commun 280:664-674

40. Wahl HG, Kausch C, Machicao F et al (2002) Troglitazone downregulates $\delta 6$ desaturase gene expression in human skeletal muscle cell cultures. Diabetes 51:1060-1065

41. Park KS, Ciaraldi TP, Lindgren K et al (1998) Troglitazone effects on gene expression in human skeletal muscle of type II diabetes involve up-regulation of peroxisome proliferator-activated receptor- $\gamma$. J Clin Endocrinol Metab 83:2830-2835

42. Park KS, Ciaraldi TP, Abrams-Carter L et al (1998) Troglitazone regulation of glucose metabolism in human skeletal muscle cultures from obese type II diabetic subjects. J Clin Endocrinol Metab 83:1636-1643

43. Yonemitsu S, Nishimura H, Shintani M et al (2001) Troglitazone induces GLUT4 translocation in L6 myotubes. Diabetes 50:1093-1101

44. Seda O, Kazdova L, Krenova D, Kren V (2002) Rosiglitazone improves insulin resistance, lipid profile and promotes adiposity in a genetic model of metabolic syndrome X. Folia Biol (Praha) 48:237-241

45. Musi N, Goodyear LJ (2003) AMP-activated protein kinase and muscle glucose uptake. Acta Physiol Scand 178:337-345

46. Jessen N, Pold R, Buhl ES et al (2003) Effects of AICAR and exercise on insulin-stimulated glucose uptake, signaling, and GLUT-4 content in rat muscles. J Appl Physiol 94:1373-1379

47. Kurth-Kraczek EJ, Hirshman MF, Goodyear LJ, Winder WW (1999) 5' AMP-activated protein kinase activation causes GLUT4 translocation in skeletal muscle. Diabetes 48:16671671

48. Abbud W, Habinowski S, Zhang J-Z et al (2000) Stimulation of AMP-activated protein kinase (AMPK) is associated with enhancement of GLUT1-mediated glucose transport. Arch Biochem Biophys 380:347-352

49. Giannarelli R, Aragona M, Coppelli A, Del Prato S (2003) Reducing insulin resistance with metformin: the evidence today. Diabetes Metab 29:6S28-6S35 